JETE : VOL 2 NO 2 2021* E-ISSN : 2745-9888 * P-ISSN : 2745-9896

Journal of Education and Teaching

http://ejournal.uin-suska.ac.id/index.php/JETE

\title{
PENGARUH SUPERVISI KEPALA MADRASAH DAN KOMITMEN KERJA GURU TERHADAP PROFESIONALITAS GURU PADA MADRASAH TSANAWIYAH NEGERI 1 KOTA PEKANBARU
}

\author{
Mardhiyah $^{1}$ \\ MTsN 1 Kota Pekanbaru \\ maymardhiyah@gmail.com
}

Received: 30 Oktober 2019; Accepted 12 Agustus 2021; Published 1 September 2021

Ed 2021; 2 (2): 225-235

\begin{abstract}
ABSTRAK
Pengaruh supervisi Kepala Madrasah dan komitmen kerja guru terhadap profesionalitas guru pada MTsN 1 Kota Pekanbaru dilakukan melalui uji korelasi ganda dan uji regresi linier berganda. Melalui uji korelasi ganda terdapat pengaruh yang signifikan antara supervisi Kepala Madrasah dengan profesionalitas guru, hal ini diperoleh nilai sig. untuk supervisi Kepala Madrasah sebesar 0.000. Hasil ini jika dibandingkan dengan nilai probabilitas 0.05 , maka ia lebih kecil $(0.000<$ 0.05). Selain uji korelasi ganda juga dilakukan uji regresi linier berganda hasil analisis signifikan dengan nilai $F$ sebesar 11.066 dengan signifikansi 0.000 . Nilai taraf signifikansi 0.00 tersebut adalah lebih rendah dari pada 0.05 , sehingga dapat disimpulkan bahwa supervisi Kepala Madrasah dan komitmen kerja guru secara bersama berpengaruh terhadap profesional guru di MTsN 1 Kota Pekanbaru, dengan taraf siginifikansi 0.00. maka Kepala Madrasah perlu terus melakukan Pengembangan supervisi dan program-program peningkatan komitmen kerja guru di MTsN 1 Kota Pekanbaru agar profesional guru tetap terus terjaga.
\end{abstract}

Kata Kunci: Guru Profesional, Uji Korelasi Ganda, Uji Regresi Linier

Berganda

\section{ABSTRACT}

The influence of Madrasah Principal supervision and teacher work commitment on teacher professionalism at MTsN 1 Pekanbaru City was carried out through multiple correlation tests and multiple linear regression tests. Through the multiple correlation test, there is a significant effect between the supervision of the Madrasah Head and the professionalism of the teacher, this is obtained by the value of sig. for the supervision of the Madrasah Head of 0.000. This result when compared with the probability value of 0.05 , it is smaller $(0.000<0.05)$. In addition to the multiple correlation test, multiple linear regression tests were also 
carried out with significant analysis results with an $F$ value of 11,066 with a significance of 0.000. The significance level of 0.00 is lower than 0.05, so it can be concluded that the supervision of the Madrasah Principal and the commitment of teachers to work together have an effect on teacher professionalism at MTsN 1 Pekanbaru City, with a significance level of 0.00. the Head of Madrasah needs to continue to develop supervision and programs to increase teacher work commitment at MTsN 1 Pekanbaru City so that teacher professionalism is maintained.

Keywords: Professional Teacher, Multiple Correlation Test, Multiple Linear Regression

\section{PENDAHULUAN}

Guru merupakan salah satu kunci keberhasilan dalam pendidikan, karena keberadaan guru sangat berpengaruh terhadap semua sumber daya pendidikan yang ada. Berbagai sumber daya pendidikan seperti, sarana dan prasarana, biaya, teknologi, informasi, siswa dan orang tua siswa dapat berfungsi dengan baik apabila guru memiliki kemampuan yang baik pula dalam menggunakan semua sumber daya yang ada. Selain itu, kualitas pendidikan akan terwujud jika proses belajar mengajar di kelas berlangsung dengan baik, dalam arti guru yang melaksanakan proses belajar mengajar telah melakukan perencanaan pembelajaran, pelaksanaan pembelajaran sampai evaluasi pembelajaran secara terpadu. Menurut Indra Djati Sidi dalam (Syaukani, 2002:51) yang temasuk dalam peningkatan kualitas pendidikan adalah kemampuan guru dalam mengelola proses belajar mengajar di kelas, dimana fungsi guru tidak menjadi satu-satunya sumber belajar, tetapi beralih sebagai pelatih (coach), pembimbing (counselor), dan manajer belajar (learning teacher).

Dengan tanggung jawab yang besar seorang guru dituntut untuk menjadi profesional. Menurut Uzer Usman (2005:15) guru profesional adalah orang yang memiliki kemampuan dan keahlian khusus dalam bidang keguruan sehingga ia mampu melakukan tugas dan fungsinya sebagai guru dengan kemampuan maksimal. Peningkatan ketrampilan profesional guru dapat dilakukan dengan berbagai upaya, antara lain melalui lembaga pre-service education, in-service education, dan on-service education (Piet A. Sahertian dan Ida Aleida Sahertian, 1992:2). yang termasuk pada in-service education adalah diantaranya adalah supervisi pendidikan. Supervisi sebagai salah satu upaya untuk meningkatkan profesionalitas guru harus dilaksanakan secara maksimal (Oteng Sutrisna, 1979:17).

Profesionalitas guru tersebut, akan terwujud dengan baik jika diiringi dengan supervisi yang dilakukan oleh kepala sekolah yang bertanggung jawab atas proses pendidikan di sekolah. Kepala sekolah bertanggungjawab dengan peningkatan mutu sumber daya manusia, peningkatan profesionalisme guru, karyawan dan semua yang berhubungan dengan sekolah berada dibawah naungan supervisi kepala sekolah. Berdasarkan fenomena yang penulis temukan, supervisi yang sering dilakukan oleh Kepala Madrasah, hal ini terlihat dari jadwal supervisi Kepala Madrasah untuk para guru di kelas masing-masing sudah tersusun dengan 
baik dan terdapat pembinaan oleh Kepala Madrasah terkait dengan metode pembelajaran di MTsN 1 Kota Pekanbaru. Begitu juga pada aspek komitmen kerja yang dimiliki oleh para guru sudah baik. Hal ini terlihat pada indikasi sebagai berikut:

1. Para guru di MTsN 1 Kota Pekanbaru terlibat aktif dalam proses pembelajaran daring;

2. Tidak terdapat guru di MTsN 1 Kota Pekanbaru yang berniat untuk pindah tugas ke sekolah lain;

3. Terdapat pengakuan dari beberapa guru bahwa selama mereka mengajar di MTsN 1 Kota Pekanbaru merasa senang dan bahagia;

4. Pada periode Januari 2021, tidak terdapat kasus guru di MTsN 1 Kota Pekanbaru yang bermasalah. Baik mengenai kedisiplinan dalam kehadiran maupun dalam melaksanakan tugas lain sebagai guru;

5. Para guru aktif mengikuti kegiatan-kegiatan lain selain dari tugas mengajar, misalnya pelatihan daring.

Namun demikian, profesionalitas guru di MTsN 1 Kota Pekanbaru masih rendah. Hal ini terlihat dari beberapa indikasi sebagai berikut:

1. Para guru MTsN 1 Kota Pekanbaru masih menggunakan metode pembelajaran yang tidak variatif, yakni sering menggunakan metode ceramah saja.

2. Penyusunan Rencana Program Pembelajaran (RPP), sering dilakukan dengan copy paste dari teman atau RPP sebelumnya.

Berdasarkan fenomena di atas, penulis tertarik untuk menulis tentang pengaruh supervisi dan komitmen kerja guru terhadap profesionalitas guru pada Madrasah Tsanawiyah Negeri 1 Kota Pekanbaru.

\section{METODE PENELITIAN}

Penelitian ini dapat digolongkan sebagai penelitian lapangan (field research) dengan pendekatan kuantitatif, yakni suatu proses menemukan pengetahuan yang menggunakan data berupa angka sebagai alat untuk menemukan keterangan mengenai apa yang ingin diketahui (S. Margono, 2004:105). Metode yang digunakan dalam penelitian ini adalah metode korelasi dengan teknik analisis regresi. Teknik ini, digunakan untuk mengukur besarnya pengaruh variable bebas terhadap variable tergantung (Jonathan Sarwono, 2009:92).

Teknik pengumpulan data dalam penelitian ini dilakukan melalui angket, wawancara dan dokumentasi. Teknik analisa data yang dipakai dalam penelitian ini adalah dengan menggunakan analisis regresi linier berganda (multiple regression). Teknik ini digunakan untuk mengetahui hubungan antara variabel bebas dengan variabel terikat. Selain itu juga untuk mengetahui sejauh mana besarnya pengaruh suervisi $\left(\mathrm{X}_{1}\right)$ dan komitmen guru $\left(\mathrm{X}_{2}\right)$ terhadap profesionalitas guru (Y).

\section{HASIL DAN PEMBAHASAN}

\section{Tolak Ukur Profesionalisme Guru}

Profesional adalah bidang pekerjaan yang dilandasi pendidikan keahlian (keterampilan, kejuruan dan sebagainya) tertentu (Syafruddin Nurdin dan M. 
Basyiruddin Usman:2002,15). Profesi menuju pada suatu kerja atau jabatan yang menuntut keahlian tanggung jawab dan kesetiaan terhadap profesi. Suatu profesi secara teori tidak bisa dilakukan oleh sembarang orang yang tidak dilatih dan disiapkan untuk itu (Dedi Supriyadi,1999:95). Profesi biasanya diukur berdasarkan kepentingan dan tingkat kesulitan yang dimiliki. Dalam dunia keprofesian kita mengenal berbagai terminologi kualifikasi profesi yaitu: yaitu profesi, semi profesi, terampil, tidak terampil, dan quasi profesi. Gilley dan Eggland mendefenisikan profesi sebagai bidang usaha manusia berdasarkan pengetahuan, dimana keahlian dan pengalaman pelakunya diperlukan oleh masyarakat. Defnisi ini meliputi aspek yaitu: ilmu pengetahuan tertentu, aplikasi kemampuan/kecakapan, dan berkaitan dengan kepentingan umum. Aspek-aspek yang terkandung dalam profesi tersebut juga merupakan standar pengukuran profesi guru. Proses profesional adalah proses evolusi yang menggunakan pendekatan organisasi dan sistematis untuk mengembangkan profesi ke arah status profesional (peningkatan status) (Aan Hasanah,2012:1).

Menurut Suharsimi Arikunto (1993:239), kompetensi profesional mengharuskan guru memiliki pengetahuan yang luas dan dalam tentang subject matter (bidang studi) yang akan diajarkan serta penguasaan metodologi yaitu menguasai konsep teoretik, maupun memilih metode yang tepat dan mampu menggunakannya dalam proses belajar mengajar. Jadi, yang dimaksud profesionalisme guru dalam penelitian ini adalah kompetensi profesional yang dimiliki oleh guru, yaitu orang yang memiliki kemampuan dan keahlian khusus dalam bidang keguruan sehingga ia mampu melaksanakan tugas dan fungsinya sebagai guru dengan maksimal. Peningkatan keterampilan profesional guru dapat dilakukan dengan berbagai upaya, antara lain melalui lembaga pre-service education, in-service education, dan on-service education.

Piet A. Sahertian dan Ida Aleida Sahertian, mengelompokkan supervisi pengajaran ke dalam program in-service education. Hal ini dapat diketahui dari usaha-usaha pengembangan yang mereka kemukakan. Usaha-usaha tersebut meliputi :

1). Usaha mempercepat pengangkatan dan penempatan;

2). Usaha perlindungan jabatan melalui jaminan hukum terhadap jabatan;

3). Pertumbuhan dan pembinaan dalam profesi.

Profesionalisme guru merupakan kondisi, arah, nilai, tujuan dan kualitas suatu keahlian dan kewenangan dalam bidang pendidikan dan pengajaran yang berkaitan dengan pekerjaan seseorang yang menjadi mata pencaharian. Sementara itu, guru yang profesional adalah guru yang memiliki kompetensi yang dipersyaratkan untuk melakukan tugas pendidikan dan pengajaran. Dengan kata lain, maka dapat disimpulkan bahwa pengertian guru profesional adalah orang yang memiliki kemampuan dan keahlian khusus dalam bidang keguruan sehingga ia mampu melakukan tugas dan fungsinya sebagai guru dengan kemampuan Maksimal seorang guru profesional hendaknya menguasai 4 kompetensi yaitu 1 . Kompetensi pedagogik yaitu kemampuan guru dalam mengelola pembelajaran peserta didik. 2. Kompetensi Profesional. Yaitu kompetensi kemampuan guru dalam mengikuti perkembangan ilmu terkini karena perkembangan ilmu selalu dinamis. 3. Kompetensi sosial hal ini bisa dilihat apakah seorang guru bisa 
bermasyarakat dan bekerja sama dengan peserta didik serta guru-guru lainnya. 4 . Kompetensi Kepribadian. Kompetensi ini terkait dengan guru sebagai teladan, beberapa aspek kompetensi ini misalnya: dewasa, stabil, arif dan bijaksana, berwibawa, mantap, berakhlak mulia, menjadi teladan bagi peserta didik dan masyarakat, mengevaluasi kinerja sendiri, mengembangkan diri secara berkelanjutan (Jhon Helmi, M.P,2015:16). Penulis menilai guru yang profesional adalah guru yang mampu menguasai materi pelajaran dengan menerapkan metode pembelajaran yang bervariasi sehingga mampu meningkatkan hasil belajar siswa dan materi yang dipelajari siswa dengan mudah dimengerti dan diamalkan dalam kehidupan sehari-hari.

\section{Pengaruh Supervisi Kepala Madrasah Dan Komitmen Kerja Guru Terhadap Profesionalitas Guru Pada Madrasah Tsanawiyah Negeri Kota Pekanbaru}

Perkataan supervisi berasal dari bahasa Inggris supervision yang terdiri dari dua perkataan yaitu super dan vision. Super berarti atas atau lebih, sedangkan vision berarti melihat atau meninjau. Oleh karena secara etimologi supervisi (supervision) berarti melihat atau meninjau dari atas atau menilik dan menilai dari atas yang dilakukan pihak atasan (orang yang memiliki kelebihan) terhadap perwujudan kegiatan dan hasil kerja bawahan (Hadari Nawawi,1981:103). Pada hakekatnya supervisi adalah sebagai bantuan dan bimbingan professional bagi guru dalam melaksanakan tugas intruksional guna memperbaiki hal belajar dan mengajar dengan melakukan stimulasi, koordinasi, dan bimbingan secara kontinyu untuk meningkatkan pertumbuhan jabatan guru secara individual maupun kelompok (Binti Maunah, 2009:14).

Perkembangan supervisi dewasa ini lebih menekankan kepada upaya guru untuk mengembangkan kualitas pembelajarannya melalui pengembangan keprofesionalan berkelanjutan. Hubungan perkembangan pengetahuan dan teknologi yang berkembangan pesat dalam waktu yang sangat singkat, supervisor dengan jumlah yang sangat terbatas dan dengan kemampuan yang variatif sehingga tidak mampu melayani kebutuhan supervisi guru dalam jumlah yang besar. Guru perlu berinisiatif menganalisis kualitas pembelajaran dan menemukan permasalahan pembelajaran untuk diupayakan peningkatan kualitasnya secara berkelanjutan. Supervisor lebih berperan sebagai fasilitator untuk terjadinya pengembangan keprofesionalan guru secara berkelanjutan tersebut. Di samping itu, menumbuhkan motivasi guru yang tinggi untuk selalu meningkatan keprofesionalannya (Ahmad Sabandi, 2013:3). Dengan demikian tujuan supervisi pendidikan adalah mengembangkan situasi pembelajaran yang lebih baik, melalui pembinaan dan peningkatan profesi pembelajaran. Penulis melakukan penyebaran angket untuk mengetahui tingkat pelaksanaan supervisi Kepala Madrasah MTsN 1 Kota Pekanbaru. Selanjutnya dilakukan penghitungan secara statistik deskriptif dari hasil angket tersebut, yaitu pada variabel Supervisi Kepala Madrasah di MTsN 1 Kota Pekanbaru, maka dapat dilihat pada tabel berikut : 
Tabel I.2

Distribusi Skor Data Supervisi Kepala Madrasah

\begin{tabular}{|c|c|c|}
\hline \multicolumn{3}{|c|}{ Statistics } \\
\hline \multicolumn{3}{|c|}{ Supervisi } \\
\hline \multirow[t]{2}{*}{$\mathrm{N}$} & Valid & 92 \\
\hline & Missing & 0 \\
\hline \multicolumn{2}{|c|}{ Mean } & 86.73 \\
\hline \multicolumn{2}{|c|}{ Median } & 86.00 \\
\hline \multicolumn{2}{|c|}{ Mode } & $80^{\mathrm{a}}$ \\
\hline \multicolumn{2}{|c|}{ Minimum } & 80 \\
\hline \multicolumn{2}{|c|}{ Maximum } & 95 \\
\hline
\end{tabular}

Dari distribusi skor supervisi madrasah pada tabel tersebut, dapat diketahui bahwa nilai terendah dari supervisi Kepala Madrasah adalah 80 sementara nilai tertingginya adalah 95. Sementara nilai mean-nya adalah 86.73 nilai median-nya 86.00, serta modusnya adalah 80. Dari perhitungan ini, untuk supervisi Kepala Madrasah di atas, menunjukkan bahwa antara nilai mean dan mediannya tidak memiliki perbedaan yang jauh. Artinya, data tentang supervisi Kepala Madrasah tersebut, cenderung berdistribusi normal. Kemudian untuk mengetahui data tentang komitmen kerja guru penulis ambil dari para guru yang menjadi sampel dalam penelitian ini, yaitu berjumlah 76 guru, namun yang mengembalikan angket hanya 68 guru hasil data tersebut dapat dilihat pada tabel di bawah ini:

Tabel I.3

Distribusi Skor Komitmen Kerja Guru

\begin{tabular}{|l|lr|}
\hline \multicolumn{2}{|c|}{ Statistics } \\
\hline \multicolumn{2}{|l|}{ Komitmen } & \\
\hline $\mathrm{N}$ & Valid & \\
\cline { 2 - 3 } & Missing & 02 \\
\hline Mean & & 83.72 \\
\hline Median & & 83.00 \\
\hline Mode & $82^{\mathrm{a}}$ \\
\hline Minimum & 75 \\
\hline Maximum & 96 \\
\hline a. Multiple modes exist. The smallest value is shown \\
\hline
\end{tabular}

Dari distribusi skor pada tabel tersebut, dapat diketahui bahwa nilai terendah dari komitmen kerja guru siswa di MTsN 1 Kota Pekanbaru adalah 75, sementara nilai tertingginya adalah 96. Sementara nilai mean-nya adalah 83.72 dan nilai median-nya 83.00, serta modusnya adalah 82. Dari perhitungan ini, menunjukkan bahwa antara nilai mean dan mediannya tidak memiliki perbedaan yang jauh. Artinya, data tentang komitmen kerja guru tersebut, cenderung berdistribusi normal. Kemudian penulis mengajukan angket untuk mengetahui tentang profesional guru, terdiri dari 30 item pernyataan yang disebar kepada seluruh 
responden, yaitu 76 guru sebagai sampel penelitian, namun yang mengembalikan hanya 68 guru di MTsN 1 Kota Pekanbaru. Artinya terdapat 8 angket yang tidak dikembalikan oleh responden, sehingga tidak dapat untuk dijadikan analisis. Oleh karena itu, data untuk menganalisis tingkat komitmen kerja Guru ini, dilakukan terhadap 68 angket yang telah diberikan oleh responden. Berikut adalah hasil deskripsi frekuensi dari data yang diperoleh dapat dilihat pada tabel di bawah ini:

Tabel I.3

Deskripsi Data Profesional Guru

\begin{tabular}{|c|c|c|}
\hline \multicolumn{3}{|c|}{ Statistics } \\
\hline \multicolumn{3}{|c|}{ Profesional } \\
\hline \multirow[t]{2}{*}{$\mathrm{N}$} & Valid & 92 \\
\hline & Missing & 0 \\
\hline \multicolumn{2}{|c|}{ Mean } & 86.38 \\
\hline \multicolumn{2}{|c|}{ Median } & 87.00 \\
\hline \multicolumn{2}{|c|}{ Mode } & 90 \\
\hline \multicolumn{2}{|c|}{ Minimum } & 73 \\
\hline \multicolumn{2}{|c|}{ Maximum } & 96 \\
\hline
\end{tabular}

Dari distribusi skor profesional guru pada tabel tersebut, dapat diketahui bahwa nilai terendah dari profesional guru adalah 73. Sementara nilai tertingginya adalah 96. Sementara nilai mean-nya adalah 86.38 nilai median-nya 87.00 , serta modusnya adalah 90. Dari perhitungan ini, untuk profesional guru tersebut di atas, menunjukkan bahwa antara nilai mean dan mediannya tidak memiliki perbedaan yang jauh. Artinya, data yang diperoleh tentang profesional kerja guru tersebut, cenderung berdistribusi normal. Untuk mengetahui hubungan yang signifikan secara bersama-sama antara supervisi kepala sekolah dan komitmen kerja guru dengan profesional guru di MTsN 1 Kota Pekanbaru penulis melakukan uji korelasi ganda. Pengambilan keputusan tentang hal ini, dilakukan dengan melihat nilai probabilitasnya, yaitu 0.05 dengan nilai probabilitas sig. Jika nilai probabilitas 0.05 , lebih kecil atau sama dengan nilai probabilitas $F_{\text {change }}(0.05 \leq$ Sig. $F_{\text {change }}$ ), maka terdapat hubungan secara bersama antara Supervisi Kepala Sekolah dan Komitmen Kerja Guru dengan professional guru di MTsN 1 Kota Pekanbaru. Akan tetapi, jika nilai probabilitas 0.05, lebih besar atau sama dengan nilai probabilitas $F_{\text {change }}\left(0.05 \geq \mathrm{Sig}\right.$. $\left.\mathrm{F}_{\text {change }}\right)$, maka tidak terdapat hubungan secara bersama antara Supervisi Kepala Sekolah dan komitmen kerja guru dengan profesional guru di MTsN 1 Kota Pekanbaru. Bisa juga dengan cara melihat tanda bintang $(* * / *)$ pada variabel yang diuji. Yaitu, tanda bintang dua (**) menunjukkan hubungan yang sangat tinggi, sementara jika ada tanda bintang satu (*) menunjukkan hubungan yang tinggi. Untuk hasil uji korelasi ganda dapat dilihat pada tabel di bawah ini: 
Tabel I.4

Korelasi Ganda Supervisi Kepala Madrasah Dan Komitmen Kerja Guru Terhadap Profesional Guru

\begin{tabular}{|c|c|c|c|c|}
\hline \multicolumn{5}{|c|}{ Correlations } \\
\hline & & $\mathrm{X} 1$ & $\mathrm{X} 2$ & $\mathrm{Y}$ \\
\hline \multirow[t]{3}{*}{$\mathrm{X} 1$} & Pearson Correlation & 1 & $.542^{* *}$ & $.401^{* *}$ \\
\hline & Sig. (2-tailed) & & .000 & .000 \\
\hline & $\mathrm{N}$ & 92 & 92 & 92 \\
\hline \multirow[t]{3}{*}{$\mathrm{X} 2$} & Pearson Correlation & $.542^{* *}$ & 1 & $.381^{* *}$ \\
\hline & Sig. (2-tailed) & .000 & & .000 \\
\hline & $\mathrm{N}$ & 92 & 92 & 92 \\
\hline \multirow[t]{3}{*}{ Y } & Pearson Correlation & $.401^{* *}$ & $.381^{* * *}$ & 1 \\
\hline & Sig. (2-tailed) & .000 & .000 & \\
\hline & $\mathrm{N}$ & 92 & 92 & 92 \\
\hline
\end{tabular}

Berdasarkan hasil dari tabel corelation di atas, diperoleh nilai sig untuk supervisi Kepala Madrasah sebesar 0.000. Hasil ini jika dibandingkan dengan nilai probabilitas 0.05 , maka ia lebih kecil $(0.000<0.05)$. Sehingga bisa disimpulkan bahwa terdapat korelasi yang signifikan antara supervisi Kepala Madrasah dengan profesional guru. Sementara untuk komitmen kerja guru diperoleh nilai sig. sebesar 0.000. Hasil ini jika dibandingkan dengan nilai probabilitas 0.05, maka juga masih ia lebih kecil dari 0.05 (0.000 > 0.05). Sehingga bisa disimpulkan bahwa terdapat korelasi yang signifikan antara supervisi kepala sekolah dan komitmen kerja guru dengan profesional guru di MTsN 1 Kota Pekanbaru. Selain uji korelasi ganda penulis juga melakukan uji regresi linier berganda Berikut ini, disajikan hasil perhitungan analisis regresi terhadap variabel supervisi kepala sekolah dan komitmen kerja guru dengan profesional guru di MTsN 1 Kota Pekanbaru, melalui program SPSS 22. Hasil perhitungannya dapat dilihat pada tabel berikut ini, yaitu:

\section{Tabel I.5}

Anova Regresi Supervisi Kepala Madrasah dan Komitmen Kerja Guru Terhadap Profesional Guru

\begin{tabular}{|c|c|c|c|c|c|c|}
\hline \multicolumn{7}{|c|}{ ANOVA $^{\text {b }}$} \\
\hline \multicolumn{2}{|c|}{ Model } & Sum of Squares & Df & Mean Square & $\mathrm{F}$ & Sig. \\
\hline \multirow[t]{3}{*}{1} & Regression & 549.176 & 2 & 274.588 & 11.066 & $.000^{\mathrm{a}}$ \\
\hline & Residual & 2208.509 & 89 & 24.815 & & \\
\hline & Total & 2757.685 & 91 & & & \\
\hline \multicolumn{7}{|c|}{ a. Predictors: (Constant), X2, X1 } \\
\hline \multicolumn{7}{|c|}{ b. Dependent Variabel: Y } \\
\hline
\end{tabular}

Tabel di atas merupakan uji anova untuk melihat signifikansi dari hasil regresi ganda. Berdasarkan tabel tersebut di atas, terlihat bahwa hasil analisis regresi ganda signifikan dengan nilai $\mathrm{F}$ sebesar 11.066 dengan signifikansi 0.000 . Nilai taraf signifikansi 0.00 tersebut adalah lebih rendah dari pada 0.05 , sehingga dapat disimpulkan bahwa supervisi kepala sekolah dan komitmen kerja guru 
secara bersama berpengaruh terhadap profesional guru di MTsN 1 Kota Pekanbaru, dengan taraf siginifikansi 0.00. Selanjutnya untuk melihat tingkat pengaruh antara variabel independen (supervisi Kepala Madrasah dan komitmen kerja guru) terhadap variabel dependen (profesional guru), dapat dilihat pada tabel berikut :

Tabel I.6

Ringkasan Hasil Koefisien Determinasi

Supervisi Kepala Madrasah Dan Komitmen Kerja Guru Terhadap Profesional Guru

\begin{tabular}{|c|c|c|c|c|c|c|c|c|c|}
\hline \multicolumn{10}{|c|}{ Model Summary $^{\mathbf{b}}$} \\
\hline \multirow[b]{2}{*}{ Model } & \multirow[b]{2}{*}{$\mathrm{R}$} & \multirow[b]{2}{*}{$\begin{array}{c}\mathrm{R} \\
\text { Square }\end{array}$} & \multirow[b]{2}{*}{$\begin{array}{c}\text { Adjusted R } \\
\text { Square }\end{array}$} & \multirow[b]{2}{*}{$\begin{array}{l}\text { Std. Error of } \\
\text { the Estimate }\end{array}$} & \multicolumn{5}{|c|}{ Change Statistiks } \\
\hline & & & & & $\begin{array}{c}\text { R Square } \\
\text { Change }\end{array}$ & F Change & df1 & df2 & $\begin{array}{c}\text { Sig. F } \\
\text { Change }\end{array}$ \\
\hline 1 & $.446^{\mathrm{a}}$ & .199 & .181 & 4.981 & .199 & 11.066 & 2 & 89 & .000 \\
\hline \multicolumn{10}{|c|}{ a. Predictors: (Constant), X2, X1 } \\
\hline \multicolumn{10}{|c|}{ b. Dependent Variabel: $Y$} \\
\hline
\end{tabular}

Pada tabel di atas menunjukkan korelasi ganda antara variabel variabel independen (supervisi Kepala Madrasah dan komitmen kerja guru) terhadap variabel dependen (profesional Guru) pada taraf 0.446. Sedangkan koefisien determinasinya menunjukkan nilai 0.199. Hal ini berarti, bahwa pengaruh variabel independen (supervisi Kepala Madrasah dan komitmen kerja guru) terhadap variabel dependen (profesional guru) adalah sebesar 19.9\%, sedangkan sisanya yaitu $80.1 \%$ dipengaruhi oleh variabel lain selain supervisi kepala Madrasah dan komitmen kerja guru. Kesimpulan terhadap hasil tersebut, bahwa supervisi Kepala Madrasah dan komitmen kerja guru berpengaruh terhadap Komitmen Kerja Guru di MTsN 1 Kota Pekanbaru, memiliki standar kesalahan estimasi sebesar 4.981 .

Tabel I.7

Rangkuman Analisa Regresi Linier

Supervisi Kepala Madrasah Dan Komitmen Kerja Guru Terhadap Profesional Guru

\begin{tabular}{|c|c|c|c|c|c|c|}
\hline \multicolumn{7}{|c|}{ Coefficients $^{\mathrm{a}}$} \\
\hline & & \multicolumn{2}{|c|}{$\begin{array}{l}\text { Unstandardized } \\
\text { Coefficients }\end{array}$} & \multirow{2}{*}{$\begin{array}{c}\begin{array}{c}\text { Standardized } \\
\text { Coefficients }\end{array} \\
\text { Beta } \\
\end{array}$} & \multirow[b]{2}{*}{$\mathrm{T}$} & \multirow[b]{2}{*}{ Sig. } \\
\hline \multicolumn{2}{|c|}{ Model } & $\mathrm{B}$ & Std. Error & & & \\
\hline 1 & (Constant) & 33.150 & 11.641 & & 2.848 & .005 \\
\hline & $\mathrm{X} 1$ & .301 & .123 & .276 & 2.443 & .017 \\
\hline & $\mathrm{X} 2$ & .319 & .155 & .232 & 2.056 & .043 \\
\hline & ependent Va & & & & & \\
\hline
\end{tabular}

Berdasarkan tabel di atas, dapat dilihat pada kolom B pada bagian constant muncul nilai 33.150, sedang nilai $X_{1}$ adalah 0.301 dan $X_{2}$ muncul nilai 0.319. Maka dapat dikemukakan persamaan regresi linearnya adalah sebagai berikut : $\hat{Y}$ $=33.150+0.301 \mathrm{x}_{1}+0.319 \mathrm{x}_{2}$. Standar kesalahan persamaan regresi tersebut dia 
atas adalah sebesar 11.641 untuk beta nol. Sementara standar kesalahan persamaan regresi untuk variabel Supervisi Kepala Madrasah adalah sebesar 0.123 sedangkan standar kesalahan persamaan regresi untuk variabel Komitmen Kerja Guru adalah sebesar 0.155 .

Tabel di atas, juga memberikan informasi tentang signifikansi dari analisis koefisien regresi ini. Nilai signifikansi uji t untuk variabel supervisi kepala sekolah adalah 0.017. Sementara untuk variabel semnagat kerja guru, nilai signifikansinya adalah sebesar 0.043. Hal ini menunjukkan bahwa:

1) Variabel supervisi kepala sekolah mempengaruhi profesional guru di MTsN 1 Kota Pekanbaru. Hal ini ditunjukkan dengan hasil uji t tersebut, dimana nilai signifikansinya 0.017 lebih kecil dari $0.05(0.017<0.05)$.

2) Variabel komitmen kerja guru mempengaruhi profesional guru di MTsN 1 Kota Pekanbaru. Hal ini ditunjukkan dengan hasil uji t tersebut, dimana nilai signifikansinya 0.043 lebih kecil dari $0.05(0.043<0.05)$.

3) Dari persamaan regresi tersebut di atas, juga dapat diartikan bahwa tanpa adanya variabel $\mathrm{X}_{1}$ dan $\mathrm{X}_{2}$, yaitu supervisi Kepala Madrasah dan komitmen kerja guru di MTsN 1 Kota Pekanbaru, maka kondisi profesional guru MTsN 1 Kota Pekanbaru rendah, yaitu 33.150

Dengan hasil tersebut di atas, maka Kepala Madrasah perlu terus melakukan mengembangkan supervisi Kepala Madrasah dan program-program peningkatan komitmen kerja guru di MTsN 1 Kota Pekanbaru agar profesional guru tetap terus terjaga. Hasil penelitian ini, memperkuat hasil penelitian yang dilakukan oleh Nihayatus Sholikhah (2014) yang dimana supervisi Kepala Madrasah dapat mempengaruhi upaya peningkatan mutu kompetensi pedagogik guru. Adapun kompetensi guru dapat diukur melalui: "pemahaman guru terhadap peserta didik, perencanaan dan pelaksanaan pembelajaran, penilaian evaluasi belajar." Dalam penelitian ini, Nihayatus Sholikhah hanya menyinggung supervisi Kepala Madrasah dalam meningkatkan mutu kompetensi pedagogik guru.

\section{SIMPULAN}

Kompetensi profesional mengharuskan guru memiliki pengetahuan yang luas dan dalam tentang subject matter (bidang studi) yang akan diajarkan serta penguasaan metodologi yaitu menguasai konsep teoretik, maupun memilih metode yang tepat dan mampu menggunakannya dalam proses belajar mengajar. Maksimal seorang guru profesional hendaknya menguasai 4 kompetensi yaitu 1 . Kompetensi pedagogik; 2. Kompetensi Profesional; 3. Kompetensi sosial dan 4. Kompetensi kepribadian. Peningkatan keterampilan profesional guru dapat dilakukan dengan berbagai upaya, antara lain melalui lembaga pre-service education, in-service education, dan on-service education. Adapun supervisi termasuk dalam in-service education. Pengaruh supervisi Kepala Madrasah dan komitmen kerja guru terhadap profesionalitas guru pada MTsN 1 Kota Pekanbaru dilakukan melalui uji korelasi ganda dan uji regresi linier berganda. Melalui uji korelasi ganda terdapat pengaruh yang signifikan antara supervisi kepala sekolah dengan profesionalitas guru, hal ini diperoleh nilai sig untuk supervisi Kepala Madrasah sebesar 0.000 . Hasil ini jika dibandingkan dengan nilai probabilitas 0.05 , maka ia lebih kecil $(0.000<0.05)$. Selain uji korelasi ganda juga dilakukan 
uji regresi linier berganda hasil analisis signifikan dengan nilai $\mathrm{F}$ sebesar 11.066 dengan signifikansi 0.000 . Nilai taraf signifikansi 0.00 tersebut adalah lebih rendah dari pada 0.05 , sehingga dapat disimpulkan bahwa supervisi Kepala Madrasah dan komitmen kerja guru secara bersama berpengaruh terhadap profesional guru di MTsN 1 Kota Pekanbaru, dengan taraf siginifikansi 0.00 . maka Kepala Madrasah perlu terus melakukan mengembangkan supervisi Kepala Madrasah dan program-program peningkatan komitmen kerja guru di MTsN 1 Kota Pekanbaru agar profesional guru tetap terus terjaga.

\section{DAFTAR REFERENSI}

Aan Hasanah. Pengembangan Profesi Guru. (Bandung:Pustaka Setia, 2012).

Ahmad Sabandi. Supervisi Pendidikan Untuk Pengembangan Profesionalitas

Guru Berkelanjutan, Pedagogi Jurnal Ilmiah Ilmu Pendidikan Volume XIII No.2 November 2013.

Binti Maunah, Supervisi Pendidikan Islam (Teori dan Praktik), (Yogyakarta:Teras, 2009).

Dedi Supriyadi. Mengangkat Citra dan Martabat Guru. (Yogyakarta:Adicita Karya Nusa,1999).

Hadari Nawawi. Administrasi Pendidikan. (Jakarta:Gunung Agung,1981).

Jhon Helmi, M.P. Kompetensi Profresional Guru, Jurnal Pendidikan. Al-Ishlah, Vol 7 No. 2 Tahun 2015.

Jonathan Sarwono. Statistik Itu Mudah, Belajar Lengkap Untuk Belajar Komputasi Statistik Menggunakan SPSS 16. (Yogyakarta:ANDI Offset, 2009).

Moh Uzer Usman. Menjadi Guru Profesional. (Bandung:PT. Remaja Rosdakarya, 2005).

Nihayatus Sholikhah. "Persepsi Guru Tentang Komitmen Kepemimpinan Kepala Sekolah Dan Pengaruh Terhadap Upaya Peningkatan Mutu Kompetensi Pedagogik Guru MTs Daruss'adah Bulus Kecamatan Patehan Kabupaten Kendal” Jurnal JMP. Volume 2 Nomor 2, April 2013

Oteng Sutrisna, Supervisi Dan Administrasi Pendidikan, (Jakarta:Jemmars, 1979).

Piet A. Sahertian dan Ida Aleida Sahertian. Supervisi Pendidikan Dalam Rangka Program Inservice Education. Cet 2. (Jakarta:Rineka Cipta, 1992). S.

Margono. Metodologi Penelitian Pendidikan. (Jakarta: Rineka Cipta, 2004).

Suharsimi Arikunto. Manajemen Pengajaran Secara Manusia. (Jakarta:Rineka Cipta, 1993).

Syafruddin Nurdin dan M. Basyiruddin Usman. Guru Profesional dan Implementasi Kurikulum. (Jakarta:Ciputat Press, 2002.

Syaukani. Titik Temu Dalam Dunia Pendidikan. (Jakarta:PRAJA, 2002). 